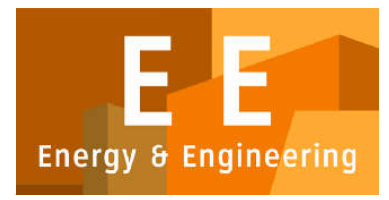

PAPER - OPEN ACCESS

\title{
Analisis Pendistribusian Panggilan Masuk ke Call Center Telkomsel Medan
}

\author{
Author $\quad$ : Johana Sihol Marito Purba dan Juliza Hidayati \\ DOI $\quad: 10.32734 /$ ee.v2i4.665 \\ Electronic ISSN $\quad: 2654-704 \mathrm{X}$ \\ Print ISSN : :2654-704X
}

Volume 2 Issue 4 - 2019 TALENTA Conference Series: Energy \& Engineering (EE)

\section{(2) $(0 \Theta$}

This work is licensed under a Creative Commons Attribution-NoDerivatives 4.0 International License.

Published under licence by TALENTA Publisher, Universitas Sumatera Utara 


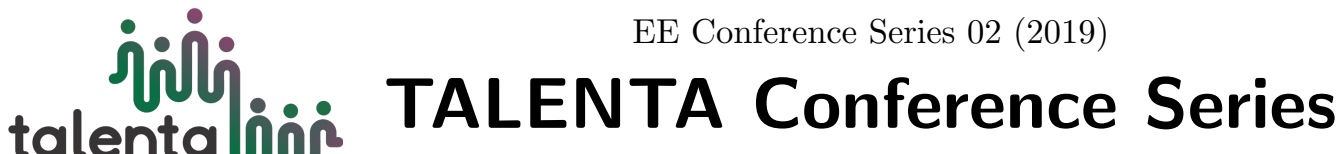

Available online at https://talentaconfseries.usu.ac.id

\section{Analisis Pendistribusian Panggilan Masuk ke Call Center Telkomsel Medan}

\author{
(Analysis of Distribution of Incoming Calls to Telkomsel Call Centers Medan) \\ Johana Sihol Marito Purba, Juliza Hidayati \\ Magister Teknik Industri - Universitas Sumatera Utara \\ johanasima@gmail.com,
}

\begin{abstract}
Abstrak
Antrian panggilan yang masuk pada suatu call center merupakan hal yang sulit dihindari karena berkaitan dengan tingkat aktivitas pelanggan. Oleh karena itu, dalam hal ini diperlukan pengukuran performance call center yang dilakukan untuk mengetahui besar kinerja dari call center tersebut. Selain itu penelitian ini penting untuk menganalisis apakah pelanggan Telkomsel mendapatkan pelayanan sesuai dengan kebutuhan masing-masing, dilihat dari jumlah panggilan yang masuk ke sistem call center dan jumlah panggilan yang berhasil dilayani oleh agent call center. Tujuan dari penelitian ini adalah untuk mengendalikan ketersediaan agent call center sehingga target service level dapat terpenuhi. Penelitian ini menggunakan metode deskriptif, yaitu metode yang bertujuan mencatat, mengolah, dan nyajikan data untuk memberikan gambaran tentang keadaan yang sebenarnya tentang perusahaan beserta pelaksanaan. Data yang terkumpul dianalisa sesuai performansi call center berupa traffic harian, pencapaian service level dan menentukan jumlah agent minimum. Hasil yang didapatkan dari penelitian ini adalah pada bulan Juni, Juli, Agustus, dan November belum mencapai target Service Level (SL) sebesar 96\%. Bila ditinjau dari ketersediaan agent, terdapat kelebihan agent pada Juni sebanyak 2 orang, namun dibulan berikutnya masih membutuhkan penambahan agent yaitu dibulan Juli sebanyak 13 orang, Agustus sebanyak 22 orang, September sebanyak

21 orang, Oktober sebanyak 3 orang dan November sebanyak 29 orang. Ketidakstabilan distribusi panggilan yang masuk ke call center mengharuskan managemen perusahaan untuk mengendalikan ketersediaan agent call center Telkomsel. Sedangkan dari peramalan call Offered didapatkan rata-rata jam sibuk yang terjadi yaitu sekitar pukul 19.00-20.00.
\end{abstract}

Kata kunci : distribusi; service level; call center; jasa;

\begin{abstract}
The queue of incoming calls at a call center is difficult to avoid because it relates to the level of customer activity. Therefore, in this case the call center performance measurement is needed to determine the performance of the call center. In addition, this study is important to analyze whether Telkomsel customers get services according to their individual needs, seen from the number of calls that enter the call center system and the number of calls successfully served by call center agents. The purpose of this study is to control the availability of call center agents so that service level targets can be met. This research uses descriptive method, a method that aims to record, process, and present data to provide an overview of the actual situation about the company and its implementation. The collected data is analyzed according to call center performance in the form of daily traffic, service level achievement and determine the minimum number of agents.The results obtained from this study are that in June, July, August, and November have not reached the Service Level (SL) target of 96\%. When viewed from the availability of agents, there are excess agents in June as many as 2 people, but in the following month still need additional agents, namely in July as many as 13 people, August as many as 22 people, September as many as 21 people, October 3 people and November 29 people. The instability of incoming call distribution to the call center requires company management to control the availability of Telkomsel call center agents. While from Call Offered forecasting, the average rush hour that occurs is around 19.00-20.00.
\end{abstract}

Keywords: distribution; service level; call center; services;

(c) 2019 The Authors. Published by TALENTA Publisher Universitas Sumatera Utara

Selection and peer-review under responsibility of Seminar Nasional Institut Supply Chain dan Logistik Indonesia (ISLI) 2019

p-ISSN: 2654-7031, e-ISSN: 2654-704X, DOI: 10.32734/ee.v2i4.665 


\section{Pendahuluan}

Secara umum perusahaan mempunya tujuan dan sasaran yang sama, yaitu keberhasilan dalan mempertahankan hidup (survive). Untuk dapat memenangkan persaingan bisnis perusahaan harus menerapkan strategi pemasaran yang tepat. Strategi tersebut meliputi, strategi produk, strategi promosi, dan strategi distribusi yang tepat dan cepat. Saluran distribusi itu sendiri mempunyai arti, seperangkat lembaga yang melakukan semua kegiatan yang digunakan untuk menyalurkan produk dan jasa dari produsen ke konsumen. Saluran distribusi dibagi menjadi dua,

yaitu saluran distribusi langsung dan saluran distribusi tidak langsung. Saluran distribusi langsung yaitu penyampaian produk atau jasa kepada konsumen yang dilakukan sendiri atau secara langsung oleh produsen. Sedangkan saluran distribusi tidak langsung yaitu penyampaian produk atau jasa kepada konsumen yang membutuhkan pihak lain sebagai perantara. Yang dimaksud pihak perantara disini adalah agen, sales, pengecer, orang yang berpengaruh, tour operator dan lain-lain.

Saluran distribusi yang digunakan oleh pihak PT. Telkomsel adalah saluran distribusi tidak langsung dimana PT Infomedia Nusantara Medan selaku Mitra Telkomsel bertugas menghandle pelayanan call center berupa pelayanan informasi, permintaan dan komplain. Pihak Telkomsel menggunakan para agent call center dengan maksud agar konsumen tidak mengeluarkan banyak waktu dan biaya untuk mendapatkan pelayanan dari Telkomsel. Call Center yang merupakan suatu kantor informasi terpusat yang bertujuan untuk menerima dan mengirimkan dengan jumlah yang besar permintaan melalui telepon. Dengan adanya layanan call center ini pelanggan Telkomsel bisa menghubungi kapan saja (24 jam) dan dimana saja.

Pada penelitian ini, akan dilakukan penilaian kinerja Call Center Telkomsel dengan menganalisa Call Center tersebut yang ditinjau dari rata-rata traffic harian sebagai penentu jam sibuk, perhitungan service level, serta menentukan jumlah agent minimum. Tujuan dari penelitian ini untuk menganalisis ketersediaan agent sehingga semua pelanggan Telkomsel yang menghubungi call center semuanya dapat dilayani.

\subsection{Tujuan Penelitian}

Tujuan dari penelitian ini adalah untuk mengendalikan ketersediaan agent di call center sehingga pelanggan Telkomsel mendapatkan pelayanan sesuai kebutuhan.

\section{Dasar Teori}

\subsection{Distribusi}

Distribusi menurut Kotler (1997) adalah kegiatan penyampaian produk dari produsen sampai kepada konsumen sebagai pemakai akhir. Dalam distribusi produk akan terbentuk suatu rantai atau saluran yang dilewati oleh produk yang disebut saluran distribusi. Saluran distribusi adalah jaringan organisasi yang melakukan fungsi-fungsi yang menghubungkan produsen dengan konsumen. Saluran distribusi terdiri dari berbagai badan / lembaga yang saling tergantung dan saling berhubungan yang berfungsi sebagai suatu system/ jaringan, yang bersama-sama berusaha menghasilkan dan mendistribusikan sebuah produk kepada konsumen (Philip Kotler, 2016:528)[2].

Bentuk saluran distribusi ini ada dua jenis yaitu:

1. Saluran Distribusi Langsung, yaitu produsen melakukan transaksi langsung kepada konsumen. Keuntungan dari distribusi langsung adalah ketika produsen menjual secara langsung kepada konsumen, mereka mempunyai control terhadap penetapan harga produsen yang ditawarkan.

2. Saliran Distribusi Tidak Langsung, yaitu produsen menyalurkan produknya melalui perantara yang kemudian disalurkan ke konsumen akhir.

\subsection{Pengertian Call Center}

Call center merupakan suatu kantor informasi yang terpusat yang digunakan untuk tujuan menerima dan mengirimkan sejumlah besar permintaan melalui telepon. Call center dioperasikan oleh sebuah perusahaan sebagai pengadministrasi layanan yang mendukung produk incoming dan menyelidiki informasi tentang konsumen. Call center dioperasikan sebagai sebuah ruang lingkup kerja yang terbuka secara luas yang dikerjakan oleh sejumlah agent call center, dilengkapi dengan sebuah work station berupa computer bagi setiap agent, sebuah telepon set/headset yang terhubungan ke jaringan telekomunikasi, dan sebuah atau lebih stasiun pengawas. 


\subsection{Call Center Telkomsel}

Pada setiap harinya, tentu banyak sekali panggilan yang masuk pada sistem call centre Telkomsel. Panggilan pertama yang masuk pada sistem akan dilayani oleh agent pertama yang tersedia. Bila kapasitas agent telah terpenuhi, maka panggilan selanjutnya yang masuk pada sistem akan berada pada kondisi antrian. Call center Telkomsel memiliki standarisasi service level (SL) sebesar 96\% yang digunakan untuk target kinerja dari call center ini. Bila kinerja dari call center mencapai $96 \%$ maka kinerja call center Telkomsel dalam kondisi bagus. Selain itu call center Telkomsel juga memiliki standarisasi untuk agentnya. Setiap agent memiliki standarisasi dengan durasi waktu 300 detik tiap panggilan.

\subsection{Traffic}

Secara umum trafik dapat diartikan sebagai perpindahan informasi dari satu tempat ke tempat lain melalui jaringan telekomunikasi. Besaran dari suatu trafik telekomunikasi diukur dengan satuan waktu, sedangkan nilai trafik dari suatu kanal adalah lamanya waktu pendudukan pada kanal tersebut. Salah satu tujuan perhitungan trafik adalah untuk mengetahui unjuk kerja jaringan (Network Performance) dan mutu pelayanan jaringan telekomunikasi (Quality of Service)[1].

\subsection{Penentu performansi call center Telkomsel}

Untuk mengetahui bagaimana performansi yang dimiliki oleh suatu call center maka dibutuhkan beberapa perhitungan yang bertujuan mengetahui kinerja dari suatu call center. Perhitungan yang digunakan dalam mengukur kinerja dari suatu call center adalah:

\section{Perhitungan Intensitas Traffic}

Data traffic harian yang digunakan terdiri dari beberapa parameter yaitu call offered, call answer, dan call abandoned. Tujuan dari merata-rata data traffic ini adalah untuk mengetahui berapa besar panggilan yang masuk dan panggilan yang diterima. Selain itu bisa didapatkan jam sibuk pada suatu kurun waktu tertentu, dimana jam sibuk ini dapat dilihat pada nilai jumlah panggilan yang masuk (call offered) yang paling tinggi[4]. Intensitas traffic menyatakan jumlah rata-rata dari panggilan-panggilan yang terjadi secara bersama-sama selama selang waktu tertentu. Intensitas trafik dapat diperoleh dengan mengalikan jumlah panggilan per waktu pengamatan dengan ratarata waktu pendudukan.

\section{$\mathbf{A}=\mathbf{Y} \times \mathbf{S}$}

Keterangan:

A: adalah Intensitas traffic

Y: adalah jumlah panggilan per satuan waktu pengamatan S: adalah mean handle time

\section{Perhitungan Service Level}

Telkomsel memiliki standarisasi untuk perhitungan nilai Service Level nya. Nilai service level dipengaruhi oleh beberapa parameter yaitu call offered, call answer in threshold, dan call abandoned in threshold[4]. Untuk mendapatkan nilai SL ini menggunakan rumus sebagai berikut :

\section{Service Level $=\frac{\text { Call Answer in threshold }}{\text { Call Offered-Call Abandone in threshold }}$}

\section{Keterangan:}

Call Offered adalah Jumlah panggilan yang masuk pada system call center. Call Answer In Threshold adalah jumlah panggilan yang diterima oleh agent tetapi memiliki waktu tunggu (delay) antrian selama kurang lebih 15 detik.

Call Abandoned In Threshold adalah jumlah panggilan yang telah terputus oleh pelanggan tetapi memiliki waktu tunggu (delay) antrian selama $<=15$ detik.

Untuk nilai service level, Telkomsel memiliki standarisasi sebesar 96\%. Nilai

service level ini mempengarui penilaian terhadap kinerja call center Telkomsel. 


\section{Perhitungan Jumlah Agent Minimum}

Perhitungan jumlah agent ini dilakukan untuk mendapatkan nilai agent minimum yang dibutuhkan oleh call center. Telkomsel memiliki rumusan sendiri untuk melakukan perhitungan jumlah agent. Berikut ini adalah rumus untuk perhitungan agent:

$$
\text { Jumlah Agen }=\frac{A \times 0,96}{K P I}
$$

Keterangan :

Agent adalah Jumlah agent minumum yang dibutuhkan (perjam) A adalah Rata-rata call offered tiap jam. 0.96 adalah Prosentase call answer (96\% dari nilai call offered)

KPI adalah Jumlah panggilan minimum yang diterima oleh agent (47 call perhari/orang)

\section{Metodologi Penelitian}

\subsection{Waktu dan Lokasi Penelitian}

Penelitian dilakukan dikantor call center Telkomsel dibawah naungan PT. Infomedia Nusantara di Jalan S. Parman No.215 Gedung Cambridge Lantai 3 Medan. Penelitian dilakukan selama 6 bulan mulai bulan Juni sampai November 2018.

\subsection{Metode Penelitian}

Pengumpulan ini menggunakan metode deskriptif, yaitu metode yang bertujuan mencatat, mengolah, dan nyajikan data untuk memberikan gambaran tentang keadaan yang sebenarnya tentang perusahaan beserta pelaksanaan.

\subsection{Teknik Pengumpulan Data}

Data yang digunakan dalam penelitian ini adalah menggunakan data primer dan data sekunder dengan teknik pengumpulan data sebagai berikut:

1. Survey. Penelitian ini menggunakan survey langsung kelapangan pada perusahaan yang dijadikan objek penelitian, sehingga akan diperoleh bahan - bahan yang akurat dan dapat dipertanggung jawabkan.

2. Wawancara. Wawancara dilakukan untuk lebih memperjelas data-data yang diperoleh dengan wawancara yang dilakukan kepada pihak perusahaan PT Infomedia Nusantara Medan

3. Studi Pustaka. Untuk kesempurnaan penelitian ini penulis mempelajari buku atau referensi tentang pemasaran, dokumen- dokumen serta studi literatur yang ada kaitannya dengan obyek penelitian.

4. Analisis Data. Analisis yang digunakan untuk mengetahui rata-rata traffic harian sebagai penentu jam sibuk, perhitungan service level, serta menentukan jumlah agent minimum.

\section{Hasil Penelitian dan Pembahasan}

\subsection{Menentukan Intensitas Traffic}

Tabel 1. Rata-rata Intensitas Traffic bulan Juni sampai November 2018

\begin{tabular}{|c|c|c|c|c|c|c|c|}
\hline \multirow{2}{*}{ No } & \multirow{2}{*}{$\begin{array}{c}\text { Service } \\
\text { Performance }\end{array}$} & \multicolumn{6}{|c|}{ Month } \\
\hline & & Juni & Juli & Agst & Sept & Okt & Nov \\
\hline$\overline{1}$ & Call Offered & 207690 & 238250 & 251200 & 241630 & 223100 & 252660 \\
\hline 2 & Call Answer & 188760 & 212784 & 234949 & 231660 & 217217 & 240240 \\
\hline 3 & Call Abandon & 1110 & 1209 & 1147 & 600 & 498 & 1054 \\
\hline
\end{tabular}




\begin{tabular}{llllllll}
\hline \multirow{2}{*}{ No } & \multicolumn{1}{c}{$\begin{array}{c}\text { Service } \\
\text { Performance }\end{array}$} & \multicolumn{1}{c}{ Month } \\
\cline { 2 - 7 } & \multicolumn{1}{c}{ Juni } & Juli & Agst & Sept & Okt & Nov \\
\hline 4 & $\begin{array}{l}\text { Average Handling } \\
\text { Time S (sec) }\end{array}$ & 332 & 299 & 281 & 280 & 290 & 292 \\
5 & $\begin{array}{l}\text { Jumlah panggilan Y } \\
\text { (call/hour) }\end{array}$ & 288 & 320 & 337 & 335 & 299 & 350 \\
6 & Intensitas Traffic A (erlang) & 26 & 26 & 26 & 26 & 24 & 28 \\
\hline
\end{tabular}

Volume Trafik, didefinisikan sebagai jumlah total waktu pendudukan. Intensitas Trafik, didefinisikan sebagai jumlah total waktu pendudukan dalam suatu selang pengamatan tertentu (per satuan waktu). Salah satu tujuan perhitungan trafik adalah untuk mengetahui unjuk kerja jaringan (Network Performance) dan mutu pelayanan jaringan telekomunikasi (Quality of Service)[5].

\subsection{Penentuan Jam sibuk}

Proses selanjutnya adalah penentuan jam sibuk dimana untuk menentukan jam sibuk ini menggunakan parameter call offered. Jam sibuk dapat diketahui dari hasil rata-rata jumlah panggilan masuk atau call offered. Dari hasil rata- rata call offered, nilai rata-rata tertinggi merupakan jam sibuk pada periode waktu tertentu. Untuk penentu jam sibuk pada bulan Juni sampai November 2018 dapat dilihat pada gambar berikut:

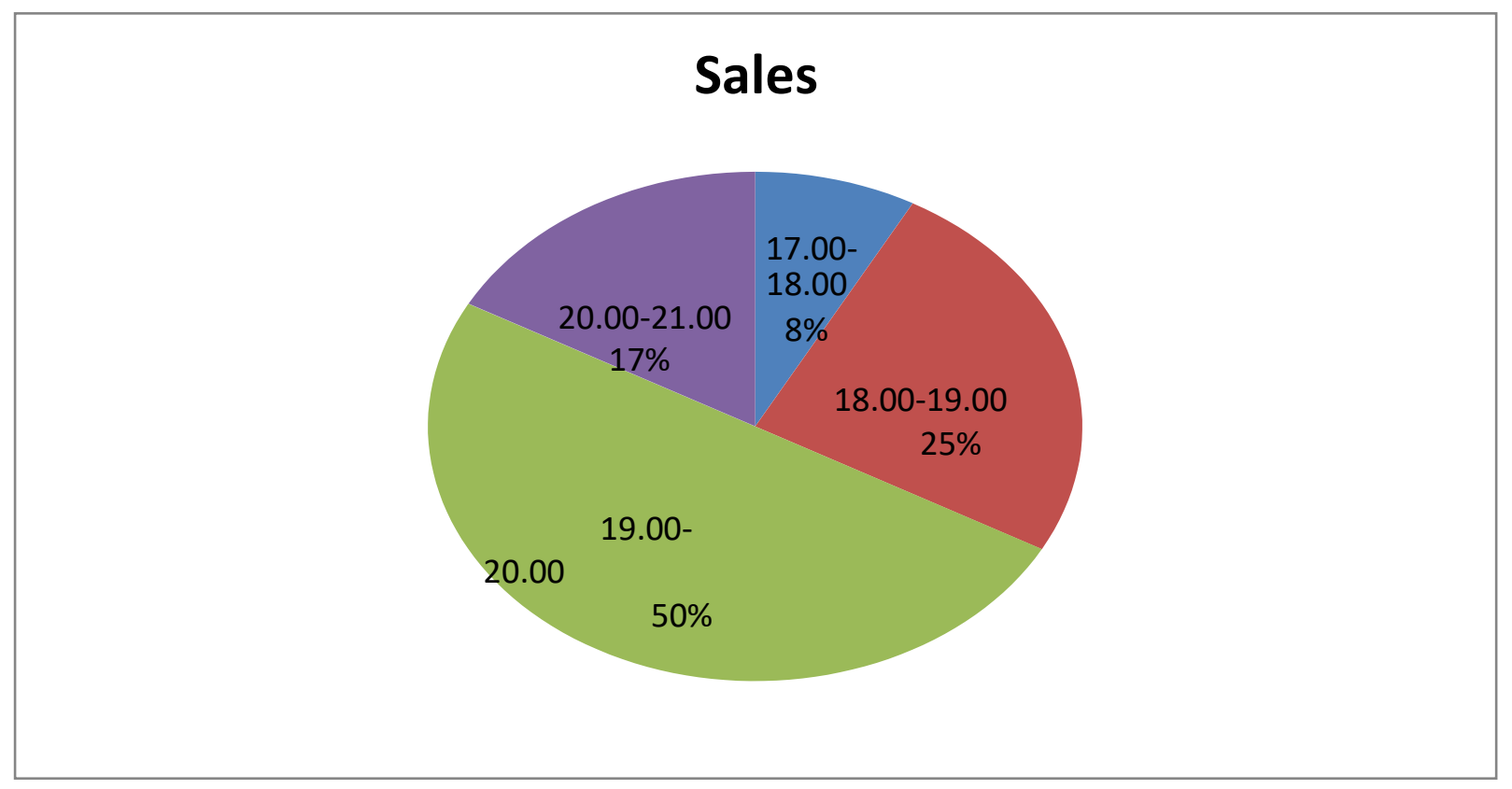

Gambar 1. Diagram Lingkaran Rata-Rata Jam sibuk

Rata-rata jam sibuk dari jam 17.00-18.00 adalah sebesar 8\%

Rata-rata jam sibuk dari jam 18.00-19.00 adalah sebesar 25\%

Rata-rata jam sibuk dari jam 19.00-20.00 adalah sebesar 50\%

Rata-rata jam sibuk dari jam 20.00-21.00 adalah sebesar 17\%

\subsection{Perhitungan Service Level}

Perhitungan yang terakhir adalah perhitungan tentang Service Level (SL). Untuk menghitung Service Lavel dibutuhkan tiga parameter yaitu call answer in threshold, call abandoned in threshold, dan call offered. Call answer in threshold merupakan jumlah panggilan yang diterima oleh agent yang memiliki waktu tunggu selama $<=15$ second. Sedangkan call abandoned in threshold merupakan jumlah panggilan yang terputus oleh pelanggan 
yang memiliki waktu tunggu $<=15$ second. Dari hasil penelitian didapatkan nilai rata-rata Service Level seperti pada grafik berikut ini:

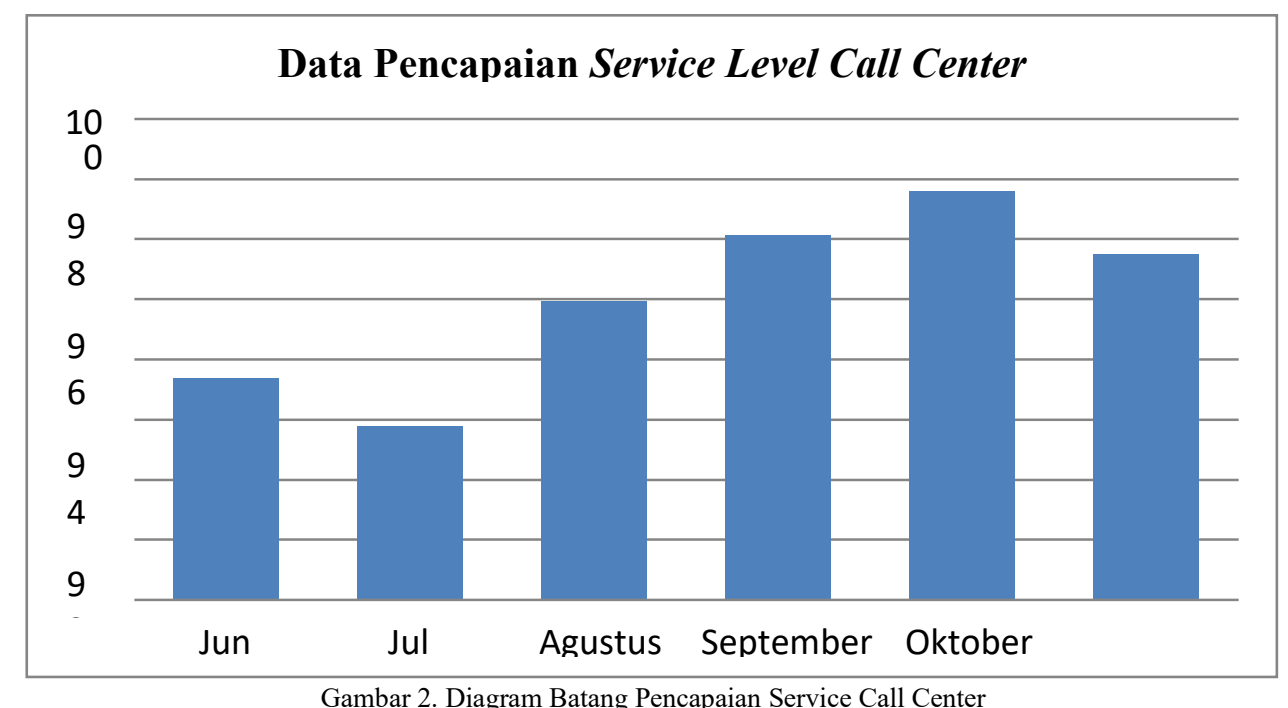

Dengan perhitungan Service Level (SL) dapat diketahui untuk nilai rata-rata Service Level pada bulan Juni sampai November 2019. Untuk bulan Juni, Juli, Agustus dan November 2018 belum memenuhi nilai standarisasi call centre yaitu minimal 96\%, hal ini dapat disebabkan karena sedikitnya panggilan yang menduduki posisi saat call answer in threshold bila dibandingkan dengan jumlah call offered.

\subsection{Perhitungan jumlah agent minimum}

Perhitungan jumlah agent ini dilakukan setiap jamnya dalam periode waktu satu bulan, jadi akan diperoleh jumlah agent pada saat jam sibuk. Hasil perhitungan jumlah agent minimum ditunjukkan dalam tabel berikut:

Tabel 2. Perhitungan jumlah agent

\begin{tabular}{lllccccc}
\hline \multirow{2}{*}{ No } & Service & Month & & & & & \\
\cline { 2 - 7 } & Performance & Juni & Juli & Agst & Sept & Okt & Nov \\
\hline 1 & $\begin{array}{l}\text { COF } \\
\text { (call/month) }\end{array}$ & 207690 & 238250 & 251200 & 241630 & 223100 & 252660 \\
& $\begin{array}{l}\text { Rata-rata call offered tiap } \\
\text { hari }\end{array}$ & 6923 & 7685 & 8103 & 8045 & 7196 & 8422 \\
& $\begin{array}{l}\text { (call/day) } \\
\text { Target SL (\%) }\end{array}$ & 96 & 96 & 96 & 96 & 96 & 96 \\
3 & $\begin{array}{l}\text { Jumlah minimum panggilan } \\
\text { yang diterima (call/orang) }\end{array}$ & 47 & 47 & 47 & 47 & 47 & 47 \\
4 & $\begin{array}{l}\text { Jumlah agent } \\
\text { minumum (orang) }\end{array}$ & 141 & 156 & 165 & 164 & 146 & 172 \\
\hline
\end{tabular}

Diketahui jumlah agent yang ada diperusahaan call center Telkomsel sebesar 143 orang, maka bulan Juni terdapat kelebihan jumlah agent dari jumlah agent minimal yang dibutuhkan, namun dibulan Juli, Agustus, September, Oktober dan November terjadi kekurangan agent, sehingga mengharuskan perusahaan untuk nemambah jumlah agentnya untuk antisipasi lonjakan panggilan atau mengharuskan agent untuk lembur supaya call yang masuk semua dapat dilayani. 


\section{Penutup}

Setelah melakukan pengujian dan analisa pada sistem perhitungan performansi call centre didapatkan beberapa kesimpulan yaitu:

5. Dari perhitungan rata-rata traffic didapatkan nilai prosentase answer pada bulan Juni sebesar $90 \%$, bulan Juli sebesar 89\%, bulan Agustus sebesar 93\%, bulan September sebesar 95\%, bulan Oktober sebesar 97\% dan bulan November sebesar 95\%. Nilai prosentase answer bulan Juli belum memenuhi standarisasi yang dimiliki oleh Telkomsel yaitu sebesar $\pm 90 \%$ dari jumlah call offered yang didapatkan.

6. Rata-rata jam sibuk terjadi pada pukul 19.00-20.00.

7. Dengan perhitungan Service Level (SL) dapat diketahui nilai rata-rata pencapaian SL bulan Juni, Juli, Agustus dan November 2018 belum memenuhi nilai standarisasi call center yaitu minimal $96 \%$.

8. Untuk ketersediaan agent, terdapat kelebihan agent pada bulan Juni sebanyak 2 orang, namun dibulan berikutnya masih membutuhkan penambahan agent yaitu dibulan Juli sebanyak 13 orang, Agustus sebanyak 22 orang, September sebanyak 21 orang, Oktober sebanyak 3 orang dan November sebanyak 29 orang.

\section{References}

[1] Hussain,Shahid. (2012) "Coordination and Monitoring Services Based on Service Level Agreements in Smart Grids" Printfabriken, Karlskrona.

[2] Keller,Kotler|. (2016) "Marketing Management" Global Edition.

[3] Kristallina,Prima (2005) "Praktikum Instalasi VoIP Server" Buku Petunjuk Praktikum.

[4] Prasetyo, Didik Dwi. (2007) “150 Rahasia Pemrograman”', PT Elex Media Komputindo.

[5] Rara, Karismawati (2009) “Analisa Performansi Dan Peramalan Call Center PT.INDOSAT, Tbk dengan Menggunakan Formula Erlang C". 